\title{
Hormone replacement therapy affects body composition and leptin differently in obese and non-obese postmenopausal women
}

\author{
K Kristensen, S B Pedersen, P Vestergaard, L Mosekilde and \\ B Richelsen
}

Department of Endocrinology and Metabolism, Aarhus University Hospital, Aarhus Amtssygehus, DK-8000, Denmark

(Requests for offprints should be addressed to K Kristensen)

\begin{abstract}
Leptin and oestrogen are both involved in the regulation of adipose tissue deposition and feeding behaviour. We investigated whether 5 years of hormone replacement therapy (HRT) affected serum leptin and body composition differently in 89 postmenopausal women treated with HRT compared with 178 controls. At baseline, leptin was significantly correlated with oestradiol $(r=0 \cdot 13$, $P<0 \cdot 05)$ and in multiple backward regression analysis including oestradiol and any estimate of body fat, oestradiol remained a significant determinant of leptin levels. In the control group, all estimates of body fat determined by dual energy X-ray absorptiometry (DEXA) or anthropometry were increased $(3.6-16.9 \%)$ and leptin increased $31.3 \%$ $(16 \cdot 03 \pm 1 \cdot 02$ to $20 \cdot 84 \pm 1 \cdot 2 \mathrm{ng} / \mathrm{ml}$ (s.E.M.), $P<0 \cdot 001)$. In the HRT group all estimates of body composition also increased during the 5-year observation but to a lesser extent than observed in the control group (1.0$8 \cdot 5 \%)$. Leptin was raised by $19 \cdot 7 \%(17 \cdot 81 \pm 1 \cdot 32$ to $20.57 \pm 1.65 \mathrm{ng} / \mathrm{ml}, \quad P<0.001)$. However, the DEXA scans revealed that the control group gained 2.4-fold more fat during the 5 -year observation $(1.9 \pm 0.3$ vs
\end{abstract}

$0.8 \pm 0.4 \mathrm{~kg}, \quad P<0.05)$, and especially the trunk fat increased $(1.4 \pm 0.2$ vs $0.7 \pm 0.3 \mathrm{~kg}, P<0.05)$. This was reflected in the increase in leptin levels, which were increased by $7 \cdot 4 \%$ in the control group compared with the HRT group $(4 \cdot 81 \pm 0 \cdot 60$ vs $2 \cdot 76 \pm 0 \cdot 87 \mathrm{ng} / \mathrm{ml}, P<0 \cdot 05)$. Adjusting for the difference in adipose tissue revealed that HRT had no independent effect on leptin levels. Comparisons between obese (body mass index $>25 \mathrm{~kg} / \mathrm{m}^{2}$ ) and non-obese $\left(<25 \mathrm{~kg} / \mathrm{m}^{2}\right)$ subjects by stratifying for HRT treatment using multiple linear regression revealed that the change in fat mass was significantly less among treated subjects $(P=0.038)$ and especially in the non-obese subjects $(P=0 \cdot 001)$. The change in trunk fat was similarly correlated with treatment status $(P=0 \cdot 029)$ and with the degree of obesity $(P=0 \cdot 006)$. In conclusion, 5 years of HRT treatment significantly reduced fat mass accumulation, especially in the trunk region. This effect of HRT was more pronounced in non-obese as compared with obese subjects. The HRT-induced reduction in fat mass seems not to be mediated by leptin.

Journal of Endocrinology (1999) 163, 55-62

\section{Introduction}

Women often experience changes in body weight in association with the menopause and clinical investigations have confirmed an increase in body weight or body mass index (BMI) (Hassager \& Christiansen 1989, Pasquali et al. 1994). The weight gain has mainly been related to an increase in body fat, and especially in adipose tissue in the abdominal region (Svendsen et al. 1995, Bjorkelund et al. 1996). Hassager \& Christiansen (1989) have demonstrated that long-term hormone replacement therapy (HRT) prevents an increase in body weight and skin-fold thickness, indicating that oestrogen may play a role in adipose tissue metabolism.

In rodents, ovariectomy increases the adipose tissue mass and oestrogen replacement reverses the fat accumulation (McElroy \& Wade 1987). Investigations in rodents have indicated that oestrogen affects the central nervous system with changes in feeding behaviour (Minami et al. 1990, Shimizu et al. 1996) and the level of physical activity (Shimizu \& Bray 1993). However, peripheral effects of oestrogen have also been reported in rodents as well as in human adipose tissue (Gray \& Wade 1980, Price et al. 1998).

Leptin is a peripherally secreted hormone involved in regulation of feeding behaviour and is thought to signal the size of adipose tissue stores to the hypothalamus. At each level of BMI there is a large variability in leptin levels, suggesting that genetic, hormonal or environmental factors may modulate leptin concentrations. In accord, hormones such as insulin and dexamethasone have been shown to stimulate leptin mRNA expression and leptin secretion in adipocytes (Masuzaki et al.1997, Kolaczynski et al. 1996, Wabitsch et al.1996) and beta-adrenergic substances 
inhibit leptin secretion from adipose tissue (Donahoo et al. 1997). Most studies have also confirmed that women have higher leptin levels than men even after adjusting for differences in body fat (Havel et al. 1996, Zimmet et al. 1996). This indicates that gender and possibly sex hormones may modulate leptin levels. In accord, a correlation between serum leptin and serum oestrogen has been reported (Hardie et al. 1997) as well as higher leptin levels in premenopausal women compared with postmenopausal (Shimizu et al. 1997). Finally, incubation of human omental adipose tissue fragments with oestrogen has shown a stimulation of leptin production in vitro (Casabiell et al. 1998).

In the present study we investigated the impact of HRT on body composition and leptin levels in postmenopausal women. In addition, the effect of HRT on body fat in obese and non-obese women was investigated. This is of interest because obesity has a significant impact on metabolic and hormonal substances such as insulin and free fatty acid (FFA), which may decrease the oestrogen effect (Vallette et al. 1988, Pedersen et al. 1991). In addition, obese subjects are considered leptin resistant (Considine et al. 1996) and therefore a change in leptin level may be sensed to a lesser degree in obese subjects.

\section{Materials and Methods}

\section{Subjects}

Five hundred and ninety-five (595) postmenopausal women were recruited to the Danish Osteoporosis Prevention Study by a short questionnaire mailed to the area population. Eighty-nine women were treated continuously with HRT and were selected as cases in the present study. For each case, two controls, never treated with HRT and matched with BMI $\left( \pm 1 \mathrm{~kg} / \mathrm{m}^{2}\right)$, were selected. The women were allocated to two groups: HRT (23 subjects by personal choice and 66 subjects by randomisation), or controls (67 subjects by personal choice and 111 subjects by randomisation). All subjects were healthy and none were being treated with drugs which influence adipose tissue metabolism. The subjects were included in the study after informed consent in accordance with the Helsinki Declaration II. The study was approved by the local Ethics Committee (\#1990/1821).

\section{Study drugs}

Sequential oral oestrogen and progesterone (Trisequens; Novo Nordisk, Bagsvaerd, Denmark) were used for women with an intact uterus $(n=69)$ and oral continuous oestradiol (Estrofem; Novo Nordisk) in hysterectomised women $(n=20)$.

\section{Methods}

Anthropometric characteristics were measured at baseline and after a 5-year follow-up. Weight was measured to the nearest $0.1 \mathrm{~kg}$ and height to the nearest $0.5 \mathrm{~cm}$. The BMI (weight in $\mathrm{kg}$ divided by the height in metres squared) was calculated. Waist circumference was measured in the supine position midway between the lower costae and the iliac crest. The hip circumference was measured at the widest part of the hip region also in the supine position and the waist:hip ratio (WHR) was calculated. WHR was only measured at baseline. Body composition was evaluated by dual energy X-ray absorptiometry (DEXA) using a QDR-1000 densitometer (Hologic, Waltham, MA, USA). The following measurements were used: total fat mass (FM), which is the sum of fat elements of soft tissue; relative fat mass (FM\%); and lean body mass (LBM), which is the sum of the chemical fat-free elements of soft tissue. As indicators of fat distribution we measured: fat localised on both legs (LF); the relative amount of fat on the legs (LF\%); fat localised on the trunk (TF); and the relative amount of the fat on the trunk. Energy intake and physical exercise were calculated from the information in a 7-day diet/exercise record.

\section{Blood parameters}

Blood parameters were measured after an overnight fast. Leptin was measured in serum samples with an RIA method (Linco Research Ltd, St Charles, MO, USA). The range of the standard curve in this assay is $0.5-100 \mathrm{ng} / \mathrm{ml}$. The intra-assay coefficient of variation (CV) was $3 \cdot 7 \%$. Serum oestradiol was measured by an AutoDelfia assay (Wallac OY, Oulunsalo, Finland); intra-assay and interassay CVs were $5 \cdot 2$ and $8 \cdot 2 \%$ respectively. Cholesterol, triglyceride (TG) and high-density lipoprotein (HDL) were measured by routine laboratory methods.

\section{Statistics}

All analyses were performed using the SPSS (SPSS Inc, Chicago, IL, USA) statistical software. Comparisons between two groups were tested with Student's paired or unpaired $t$-test when appropriate. If necessary, data were $\log$ transformed to obtain normality. Leptin concentration was $\log$ transformed in all correlations and calculations. Backward stepwise regression analysis was performed to evaluate the contributions of independent variables to the determination of leptin levels. Multiple comparisons with the change in values (delta values) as dependent variables and treatment status and BMI as independent variables were performed using multiple linear regressions. However, estimates of adipose tissue determined by DEXA are closely intercorrelated with BMI and therefore mean BMI $\left(\left(\mathrm{BMI}_{0 \text { years }}+\mathrm{BMI}_{5 \text { years }}\right) / 2\right)$ was entered as an indicator of obesity. A $P$ value of 0.05 was used as the criterion for entry at each step.

Covariance analyses were used to adjust leptin and estimates of body fat for age differences. Results are 
Table 1 Subject characteristics at inclusion time and after 5 years of observation

\begin{tabular}{|c|c|c|c|c|}
\hline \multirow[b]{2}{*}{ Time (years) } & \multicolumn{2}{|l|}{ Control } & \multicolumn{2}{|l|}{ HRT } \\
\hline & 0 & 5 & 0 & 5 \\
\hline$n$ & 178 & 178 & 89 & 89 \\
\hline Age (years) & $50 \cdot 7 \pm 0 \cdot 2$ & $55 \cdot 7 \pm 0 \cdot 2$ & $49 \cdot 8 \pm 0 \cdot 3$ & $54 \cdot 8 \pm 0 \cdot 3$ \\
\hline BMI $\left(\mathrm{kg} / \mathrm{m}^{2}\right)$ & $24 \cdot 4 \pm 0 \cdot 3$ & $25 \cdot 5 \pm 0 \cdot 3^{* * *}$ & $24 \cdot 3 \pm 0 \cdot 4$ & $25 \cdot 1 \pm 0 \cdot 5^{\star * *}$ \\
\hline $\mathrm{FM}(\mathrm{kg})$ & $20 \cdot 2 \pm 0 \cdot 6$ & $22 \cdot 0 \pm 0 \cdot 7^{\star \star *}$ & $19 \cdot 9 \pm 0 \cdot 8$ & $20 \cdot 7 \pm 1 \cdot 0^{*}$ \\
\hline LBM (kg) & $42 \cdot 4 \pm 0 \cdot 4$ & $43 \cdot 0 \pm 0 \cdot 4^{* * *}$ & $42 \cdot 4 \pm 0 \cdot 5$ & $42 \cdot 9 \pm 0 \cdot 5^{*}$ \\
\hline WHR & $0 \cdot 8 \pm 0 \cdot 01$ & - & $0 \cdot 8 \pm 0 \cdot 01$ & - \\
\hline
\end{tabular}

Student's paired $t$-test (year 5 in comparison with 0 ), ${ }^{*} P<0 \cdot 05,{ }^{* * *} P<0 \cdot 001$.

expressed as the mean \pm S.E.M. $P$ values less than 0.05 (two-way significance) were considered significant.

\section{Results}

\section{Subjects characteristics}

In Table 1 descriptive data are given for the subjects in the study. The two groups were well matched at baseline (time 0$)$ for all variables except for age $(50 \cdot 7 \pm 0 \cdot 20$ vs $49 \cdot 8 \pm 0 \cdot 30$ years, $P<0 \cdot 05$ ). Accordingly, when comparing the HRT group and the control group, the variables were corrected for age differences. There was no difference in the log-transformed serum leptin at the baseline between the two groups $(16 \cdot 0 \pm 1 \cdot 0$ vs $17 \cdot 8 \pm 1 \cdot 3 \mathrm{ng} / \mathrm{ml}$, $P=0 \cdot 09)$. At baseline there was no difference between HRT and control groups in serum oestradiol $(0 \cdot 17 \pm$ $0.02 \mathrm{nmol} / 1$ vs $0 \cdot 19 \pm 0 \cdot 03 \mathrm{nmol} / 1, P=0 \cdot 64)$. Finally, selfreported energy intakes and physical activity were equal in the groups.

Correlations between leptin, blood measurements and estimates of body fat

At baseline, leptin correlated well with BMI and most estimates of body fat $(r=0 \cdot 57-0 \cdot 75, P<0 \cdot 001)$ except with WHR $(r=0 \cdot 06, P=0 \cdot 30)$ (Table 2). A positive correlation was also found between leptin and oestradiol among all women $(r=0 \cdot 13, P<0 \cdot 05)$. In a linear backward regression

Table 2 Pearson coefficient of correlation $(r)$ between leptin and different estimates of body fat and oestradiol at baseline corrected for age $(n=267)$

\begin{tabular}{|c|c|c|}
\hline & $r$ & $P$ \\
\hline BMI & $0 \cdot 75$ & $<0.001$ \\
\hline FM & $0 \cdot 74$ & $<0.001$ \\
\hline Trunk & $0 \cdot 72$ & $<0.001$ \\
\hline Waist & 0.57 & $<0.001$ \\
\hline Lean & $0 \cdot 32$ & $<0.001$ \\
\hline Oestradiol & $0 \cdot 13$ & $<0.05$ \\
\hline WHR & 0.06 & $0 \cdot 30$ \\
\hline
\end{tabular}

analysis with leptin as the dependent variable and FM, age and oestradiol as the independent variable, oestradiol $(P<0 \cdot 005)$ and FM $(P<0 \cdot 001)$ remained significant determinants of leptin levels in all subjects. This was also found when substituting FM with BMI or FM\% in the analysis. Oestradiol was significantly correlated with the leptin:FM ratio in the whole study group $(r=0 \cdot 23, P<0 \cdot 001)$ but the association was particularly seen in the group of obese subjects $(r=0 \cdot 41, P<0 \cdot 001)$ and not among the non-obese subjects $(P=0 \cdot 70)$. No correlations were seen between oestradiol and any estimate of body composition at the baseline. Blood glucose, creatinine and cholesterol did not correlate with leptin, whereas strong associations were seen between leptin and TG $(r=0 \cdot 23, P=0 \cdot 001)$ and a negative correlation between leptin and HDL $(r=-0 \cdot 15$, $P=0 \cdot 02$ ). In multiple backward regression analysis, using leptin as the dependent variable and TG, HDL and any measurement of body fat as independent variables, only measurements of body fat remained independent predictors of leptin levels.

\section{Effects of 5 years of HRT on body composition and leptin}

After 5 years there were significant increases in all absolute and relative estimates of body fat in the control group. This was also found in the HRT group except for FM\%, LF and LF\%. However, body composition changed differently in the two groups. The increase in FM was 2-4-fold higher in the control group compared with the HRT group $(1.86 \pm 0.26$ vs $0.84 \pm 0.42 \mathrm{~kg}, P<0.05)$ (Fig. 1$)$ and also the change in $\mathrm{FM} \%$ was increased in the control group compared with the HRT group $(15.8 \pm 2.6$ vs $2 \cdot 6 \pm 3 \cdot 6 \%, P<0 \cdot 005)$. The change in FM was mainly explained by an increase in $\mathrm{TF}$ in the control group $(1.36 \pm 0.17$ vs $0.70 \pm 0.25 \mathrm{~kg}, P<0 \cdot 05)$ (Fig. 1$)$. The change in LBM was similar between the two groups (Table 1). Leptin increased in both the HRT group and the control group during the 5-year observation but the increase was significantly lower in the HRT group compared with the increase in the control group $(21 \cdot 1 \pm 4 \cdot 6$ vs $41 \cdot 8 \pm 5 \cdot 1 \%, P<0 \cdot 01)$. However, if leptin was adjusted to the FM no difference was seen between 


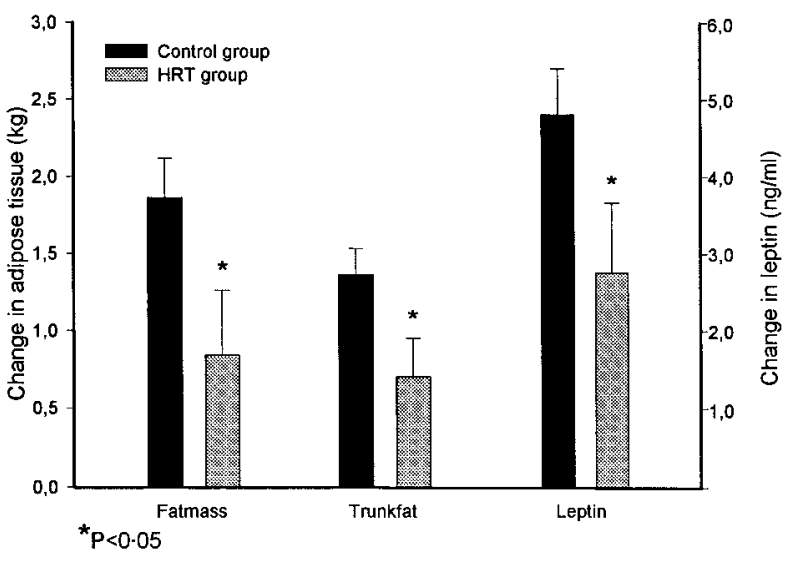

Figure 1 Effects of 5 years of HRT on the changes in fat mass, trunkfat and serum leptin.

the two groups $(P=0 \cdot 12)$. Comparing the change in leptin:FM ratio between the two groups did not reveal any differences.

\section{Obese and non-obese subjects}

To analyse if the body weight at baseline was of importance for the observed effects of HRT on body composition and leptin, the study group was divided into non-obese (BMI $<25 \mathrm{~kg} / \mathrm{m}^{2}$ ) and obese subjects $\left(\mathrm{BMI}>25 \mathrm{~kg} / \mathrm{m}^{2}\right)$. Subjects' characteristics are given in Table 3.

Non-obese subjects Within the group of non-obese subjects the changes in body weight and BMI after 5 years were similar in the control group and the HRT group. However, DEXA scans revealed significant differences in body composition. The increase in FM in the non-obese control group was almost 3-fold higher compared with the non-obese HRT group $(1.89 \pm 0.25$ vs $0.66 \pm 0.29 \mathrm{~kg}$, $P<0 \cdot 005)$ (Table 4). The increase in fat tissue was mainly located to the trunk $(1.38 \pm 0.14$ vs $0.58 \pm 0.18 \mathrm{~kg}$, $P<0 \cdot 001$ ), but also leg fat showed a tendency towards an increase in the control group compared with the HRT group $(P=0 \cdot 06)$. This was not explained by a stimulation of leptin levels in the HRT group as in fact a lesser increase in serum leptin was found in the HRT group as compared with the controls $(P<0 \cdot 05)$.

Obese subjects In the group of obese women (Table 4) the differences in absolute or relative estimates of body composition were not changed significantly between the control and the HRT group. In addition, the change in leptin after 5 years was not different between the two groups. Comparisons between obese and non-obese subjects stratifying for HRT group by using multiple linear regression revealed that the change in BMI was significantly positively correlated with obesity $(P=0.001)$ while treatment status was not $(P=0 \cdot 185)$. The change in FM was related to obesity $(P=0.001)$ and treatment status $(P=0 \cdot 038)$. The FM changed to a greater extent in obese subjects and especially among untreated subjects. This was also the seen for TF, which correlated with treatment status $(P=0.029)$ and with obesity $(P=0 \cdot 006)$. However, treatment did not affect the change in LF $(P=0.111)$, while obesity still was of significant importance $(P=0 \cdot 01)$. Analysis of delta leptin by multiple regression analysis using treatment status, obesity group and delta FM as independent variables revealed that the change in leptin

Table 3 Estimates of body fat and leptin after 5 years of observation in non-obese (BMI $<25 \mathrm{~kg} / \mathrm{m}^{2}$ ) and obese (BMI $\left.>25 \mathrm{~kg} / \mathrm{m}^{2}\right)$ subjects

\begin{tabular}{|c|c|c|c|c|}
\hline & \multicolumn{2}{|l|}{ Control } & \multicolumn{2}{|l|}{ HRT } \\
\hline & 0 years & 5 years & 0 years & 5 years \\
\hline \multicolumn{5}{|l|}{ Obese } \\
\hline Number & 64 & 64 & 32 & 32 \\
\hline Age (years) & $51 \cdot 5 \pm 0 \cdot 4$ & $56 \cdot 5 \pm 0 \cdot 4$ & $50 \cdot 3 \pm 0 \cdot 5$ & $55 \cdot 3 \pm 0 \cdot 5$ \\
\hline BMI $\left(\mathrm{kg} / \mathrm{m}^{2}\right)$ & $28 \cdot 6 \pm 0 \cdot 5$ & $30 \cdot 0 \pm 0 \cdot 5^{* *}$ & $28 \cdot 6 \pm 0 \cdot 6$ & $29 \cdot 5 \pm 0 \cdot 9$ \\
\hline $\mathrm{FM}(\mathrm{kg})$ & $28 \cdot 1 \pm 1 \cdot 1$ & $29 \cdot 9 \pm 1 \cdot 2^{*}$ & $27 \cdot 1 \pm 1 \cdot 4$ & $28 \cdot 3 \pm 2 \cdot 0$ \\
\hline $\mathrm{TF}(\mathrm{kg})$ & $12 \cdot 8 \pm 0 \cdot 6$ & $14 \cdot 1 \pm 0 \cdot 7^{* *}$ & $12 \cdot 1 \pm 0 \cdot 9$ & $13 \cdot 0 \pm 1 \cdot 1$ \\
\hline $\mathrm{LF}(\mathrm{kg})$ & $10 \cdot 9 \pm 0 \cdot 4$ & $11 \cdot 2 \pm 0 \cdot 4$ & $10 \cdot 5 \pm 0 \cdot 5$ & $10 \cdot 6 \pm 0 \cdot 7$ \\
\hline Leptin (ng/ml) & $26 \cdot 2 \pm 2 \cdot 2$ & $32 \cdot 0 \pm 2 \cdot 4^{* *}$ & $27 \cdot 5 \pm 2 \cdot 6$ & $31 \cdot 2 \pm 3 \cdot 5$ \\
\hline \multicolumn{5}{|l|}{ Non-obese } \\
\hline Number & 114 & 114 & 57 & 57 \\
\hline Age (years) & $50 \cdot 2 \pm 0 \cdot 3$ & $55 \cdot 2 \pm 0 \cdot 3$ & $49 \cdot 5 \pm 0 \cdot 4$ & $54 \cdot 5 \pm 0 \cdot 4$ \\
\hline BMI (kg) & $22 \cdot 0 \pm 0 \cdot 1$ & $23 \cdot 0 \pm 0 \cdot 2^{* *}$ & $21 \cdot 9 \pm 0 \cdot 2$ & $22 \cdot 7 \pm 0 \cdot 3^{* *}$ \\
\hline FM (kg) & $15 \cdot 7 \pm 0 \cdot 3$ & $17 \cdot 5 \pm 0 \cdot 4^{* *}$ & $15 \cdot 8 \pm 0 \cdot 4$ & $16 \cdot 4 \pm 0 \cdot 6^{*}$ \\
\hline $\mathrm{TF}(\mathrm{kg})$ & $5 \cdot 8 \pm 0 \cdot 2$ & $7 \cdot 1 \pm 0 \cdot 2^{* *}$ & $6 \cdot 0 \pm 0 \cdot 3$ & $6 \cdot 6 \pm 0 \cdot 3^{*}$ \\
\hline $\mathrm{LF}(\mathrm{kg})$ & $6 \cdot 9 \pm 0 \cdot 2$ & $7 \cdot 3 \pm 0 \cdot 2^{\star \star}$ & $6 \cdot 8 \pm 0 \cdot 2$ & $6 \cdot 9 \pm 0 \cdot 3$ \\
\hline Leptin (ng/ml) & $10 \cdot 4 \pm 0 \cdot 5$ & $14 \cdot 7 \pm 0 \cdot 9$ ** & $12 \cdot 4 \pm 0 \cdot 9$ & $14 \cdot 6 \pm 1 \cdot 0^{* *}$ \\
\hline
\end{tabular}

Student's paired $t$-test, ${ }^{*} P<0 \cdot 05,{ }^{*} P<0 \cdot 001 . F M=$ total footmass, $\mathrm{TF}=$ trunkfat, $\mathrm{LF}=$ legfat. 
Table 4 Differences $(\Delta)$ between 5 year values and baseline in estimates of body fat and leptin in non-obese $\left(\mathrm{BMI}<25 \mathrm{~kg} / \mathrm{m}^{2}\right)$ and obese $\left(\mathrm{BMI}>25 \mathrm{~kg} / \mathrm{m}^{2}\right)$ subjects

\begin{tabular}{|c|c|c|c|c|}
\hline & \multicolumn{2}{|c|}{ Non-obese } & \multicolumn{2}{|l|}{ Obese } \\
\hline & Control & HRT & Control & HRT \\
\hline$n$ & 114 & 57 & 64 & 32 \\
\hline$\Delta$-BMI $\left(\mathrm{kg} / \mathrm{m}^{2}\right)$ & $1 \cdot 0 \pm 0 \cdot 1$ & $0 \cdot 8 \pm 0 \cdot 2$ & $1 \cdot 4 \pm 0 \cdot 2$ & $0.9 \pm 0.5$ \\
\hline$\Delta$-FM $(\mathrm{kg})$ & $1 \cdot 9 \pm 0 \cdot 3$ & $0 \cdot 7 \pm 0 \cdot 3^{* *}$ & $1 \cdot 8 \pm 0 \cdot 6$ & $1 \cdot 2 \pm 1 \cdot 1$ \\
\hline$\Delta$-TF $(\mathrm{kg})$ & $1 \cdot 4 \pm 0 \cdot 1$ & $0 \cdot 6 \pm 0 \cdot 2^{* *}$ & $1 \cdot 3 \pm 0 \cdot 4$ & $0.9 \pm 0.6$ \\
\hline$\Delta-\mathrm{LF}(\mathrm{kg})$ & $0 \cdot 4 \pm 1 \cdot 1$ & $0 \cdot 1 \pm 0 \cdot 9^{*}$ & $0 \cdot 3 \pm 0 \cdot 2$ & $0 \cdot 1 \pm 0 \cdot 3$ \\
\hline$\Delta$-Leptin (ng/ml) & $4 \cdot 2 \pm 0 \cdot 6$ & $2 \cdot 3 \pm 0 \cdot 6^{*}$ & $5 \cdot 9 \pm 1 \cdot 2$ & $3 \cdot 6 \pm 2 \cdot 2$ \\
\hline
\end{tabular}

was dependent only on the change in FM $(P<0 \cdot 001)$ whereas treatment status or degree of obesity was without importance.

If the subgroup of HRT subjects treated with continuous oestrogen was investigated separately, no differences were seen compared with the group treated with sequential oestrogen and progesterone in effects on body composition and leptin levels (data not shown).

Comparison of initial leptin between weight-gainers and weight-stable subjects in the control group

It has been suggested that subjects with a disposition to weight gain have relatively low leptin levels and are of interest to identify because they might benefit from leptin treatment and avoid weight gain. We analysed subjects from the control group with a weight gain of more than $6 \mathrm{~kg}$ in 5 years and compared the initial leptin level with weight-stable subjects (weight change $\pm 0.5 \mathrm{~kg} / 5$ years) (Table 5). We found no differences between initial leptin or in leptin adjusted for FM in the two groups.

\section{Discussion}

We followed 267 postmenopausal women for 5 years and found that HRT attenuated the postmenopausal increment in FM by $60 \%$. The reduction in fat accumulation was found on the trunk and to a lesser extent on the legs. This is in agreement with studies (Haarbo et al. 1991, Gambacciani et al. 1997) where the amount of adipose tissue was measured with DEXA scans, but in contrast to other investigations. The controversy may relate to differences in the type and dosage of HRT, the length of the observation periods (Notelovitz et al. 1982, Aloia et al. 1995), the number of study subjects (Nachtigall et al. 1979, Aloia et al. 1995) or the method used for estimating adipose tissue (Kritz-Silverstein \& Barrett-Connor 1996). BMI is a biased indicator of body fatness in older women (Roubenoff et al. 1995) since adipose tissue mass increases and LBM decreases with age (Aloia et al. 1995). In addition, women who maintain their weight but lose height (osteoporotic subjects) will increase in BMI.

The clinical importance of even a modest weight loss has been proven in several investigations (Blackburn 1995). Weight loss induces a fall in blood pressure. Trials have shown that each $1 \%$ reduction in body weight leads, on average, to a fall of $1 \mathrm{mmHg}$ systolic and $2 \mathrm{mmHg}$ diastolic pressure (World Health Organization 1997). In addition, weight loss improves insulin sensitivity and in non-insulin dependent diabetes mellitus patients a weight reduction of 10-20\% has improved glycaemic control and insulin sensitivity markedly (World Health Organization

Table 5 Comparison of initial leptin between weight-gainers and weight-stable subjects in the control group. From the control group, a group of weight-gaining women $(>6 \mathrm{~kg} / 5$ years) were compared with weight-stable women $( \pm 0.5 \mathrm{~kg} / 5$ years $)$

\begin{tabular}{|c|c|c|c|c|}
\hline & Weight-stab & $(n=33)$ & Weight-gain & $h=56)$ \\
\hline & Baseline & 5 year follow-up & Baseline & 5 year follow-up \\
\hline Age (years) & $49 \cdot 9 \pm 0 \cdot 5$ & $54.9 \pm 0.5$ & $50 \cdot 4 \pm 0 \cdot 4$ & $55 \cdot 4 \pm 0 \cdot 4$ \\
\hline Leptin $(\mathrm{ng} / \mathrm{ml})$ & $16 \cdot 3 \pm 2 \cdot 1$ & $17 \cdot 1 \pm 2 \cdot 1$ & $20 \cdot 1 \pm 2 \cdot 3$ & $32 \cdot 1 \pm 2 \cdot 9$ \\
\hline Leptin/FM (ng/ml/kg) & $0 \cdot 77 \pm 0 \cdot 06$ & $0.82 \pm 0.06$ & $0 \cdot 79 \pm 0 \cdot 05$ & $1 \cdot 05 \pm 0.06$ \\
\hline $\mathrm{FM}(\mathrm{kg})$ & $20 \cdot 1 \pm 1 \cdot 6$ & $19 \cdot 9 \pm 1 \cdot 5$ & $24 \cdot 1 \pm 1 \cdot 5$ & $29 \cdot 6 \pm 1 \cdot 7$ \\
\hline
\end{tabular}

There were no differences between groups at baseline in leptin levels, suggesting that the weight-gainers do not have low leptin levels before weight gain. 
1997). It has been estimated that every $1 \mathrm{~kg}$ lost reduces low-density lipoprotein cholesterol by 1\% (World Health Organization 1997). Therefore, considering that the effects of HRT on adipose tissue were obtained during a 5 -year period, life-long treatment may have an important positive impact on cardiovascular risk factors and morbidity in postmenopausal women.

The effect of HRT on body composition was not explained by an increase in serum leptin. To investigate the impact of the initial amount of adipose tissue, the women were divided into obese and non-obese subjects. Interestingly, the protective effect of HRT on change in body composition was predominantly observed in the non-obese and to a lesser extent in the obese women. The differentiated effect of HRT on fat mass may be mediated by central effects of oestradiol as indicated by studies in rodents (Shimizu et al. 1996) or/and by direct effects on oestrogen receptors in adipocytes, but remains presently unknown. However, interaction of one hormone with its receptor is often able to affect the receptor binding of another hormone. Insulin increases the nuclear oestradiol binding in adipocytes (Pedersen et al.1991) and as insulin resistance is frequently observed in obesity, it may influence the oestrogen effect negatively in obese subjects. Elevation of FFA is also frequent in obesity and may interact negatively with the oestrogen binding (Vallette et al. 1988). Finally, obese subjects have a higher endogenous oestrogen production compared with lean subjects (Szymczak et al. 1998). The additional oestrogen load in obese subjects receiving HRT may therefore not markedly influence the limited number of oestrogen receptors in human adipocytes (Pedersen et al.1996b).

The effect of oestrogen on leptin levels is controversial. Investigations have shown that leptin levels are higher in premenopausal women compared with postmenopausal women (Rosenbaum et al. 1996, Shimizu et al. 1997). However, this is not found in all studies (Haffner et al.1997) and the disagreement may be explained by differences in age or in the fat distribution, which may influence leptin levels (Ostlund et al. 1996, Moller et al. 1998). In the luteal phase, leptin rises compared with in the follicular phase (Shimizu et al. 1997, Hardie et al. 1997). However, the menstrual cycle involves other hormones than oestradiol, as indicated in a recent study where leptin was correlated with the plasma progesterone rather than oestradiol (Hardie et al. 1997). In a recent in vitro investigation, human omental adipose tissue was incubated with supra-physiological doses of oestradiol, which raised the integrated leptin secretion after $48 \mathrm{~h}$ (Casabiell et al. 1998). However, a recent case-control study in a mixed population of obese and non-obese (Haffner et al. 1997) has not been able to demonstrate any effects of HRT on leptin levels in accord with the present follow-up study.

In the postmenopausal women, leptin correlated well with most estimates of adipose tissue as found in other investigations. However, we did not find a correlation with WHR. WHR is an indicator of intra-abdominal adipose tissue and other studies have shown that intraabdominal fat does not correlate with leptin levels (Kristensen et al. 1998). This is in accordance with studies where a decreased leptin mRNA expression (Hube et al. 1996) and leptin secretion (Masuzaki et al. 1995) were found in omental adipocytes compared with subcutaneous adipocytes (Hube et al. 1996, Montague et al. 1997). The differences in leptin secretion between omental adipocytes and subcutaneous adipocytes may relate to differences in adipocyte size, or responses to insulin or catecholamines between the two deposits.

The changes in FM and TF were equal in the oestrogen group and the oestrogen plus progesterone (Trisequens) group. This might be explained by the lack of progestin receptors in human adipose tissue (Pedersen et al. 1996a) or that the norethisteron acetate doses are too low to influence on adipocyte metabolism. In addition, norethisterone acetate is only present for 10 days in a cycle, which may be insufficient to influence long-term accumulation of adipose tissue.

In order to detect determinants for weight gain in our population we compared baseline leptin levels between weight-gaining subjects $(>6 \mathrm{~kg})$ and weight-stable subjects $( \pm 0.5 \mathrm{~kg})$ during the 5 -year follow-up. No differences between weight-gaining subjects and weight-stable subjects in baseline leptin or leptin adjusted for FM were found. This is in accordance with two studies (Haffner et al. 1998, Nagy et al. 1998) but contrasts with the findings in 36 Pima Indians by Ravussin et al. (1997), where relatively low levels of leptin were preceding weight gain. However, the Pima Indians were very obese and the weight gain considerably faster compared with the subjects in the present study $(>3.0 \mathrm{~kg} /$ year). However, slightly more men were selected to the weight-gain group (14 women and 19 men) compared with the weight-stable group (11 women and 17 men) and as men have lower leptin levels than women this might contribute to the outcome. Furthermore, ethnic differences may play an important role in these contradictory findings.

In conclusion, 5 years of HRT in postmenopausal women significantly reduced total body fat accumulation, particularly in the trunk region. This effect of HRT was more pronounced in non-obese as compared with obese subjects. The observed changes in leptin were related to changes in fat mass and accordingly leptin did not seem to be involved in the HRT-induced reduction in fat accumulation in postmenopausal women.

\section{Acknowledgements}

The technical assistance of Lenette Pedersen and Dorte Phillip is gratefully appreciated. This work was supported by Fonden til lægevidenskabens Fremme, the Danish Medical Research Council, the Aarhus University- 
Novo Nordisk Centre for Research in Growth and Regeneration and the Danish Diabetes Association.

\section{References}

Aloia JF, Vaswani A, Russo L, Sheehan M \& Flaster E 1995 The influence of menopause and hormonal replacement therapy on body cell mass and body fat mass. American Journal of Obstetrics and Gynecology 172 896-900.

Bjorkelund C, Lissner L, Andersson S, Lapidus L \& Bengtsson C 1996 Reproductive history in relation to relative weight and fat distribution. International Journal of Obesity and Related Metabolic Disorders 20 213-219.

Blackburn G 1995 Effect of degree of weight loss on health benefits. Obesity Research 3 (Suppl 2) 211S-216S.

Casabiell X, Pineiro V, Peino R, Lage M, Camina J, Gallego R, Vallejo LG, Dieguez C \& Casanueva FF 1998 Gender differences in both spontaneous and stimulated leptin secretion by human omental adipose tissue in vitro: dexamethasone and estradiol stimulate leptin release in women, but not in men. Journal of Clinical Endocrinology and Metabolism 83 2149-2155.

Considine RV, Sinha MK, Heiman ML, Kriauciunas A, Stephens TW, Nyce MR, Ohannesian JP, Marco CC, McKee LJ, Bauer TL \& Caro JF 1996 Serum immunoreactive-leptin concentrations in normal-weight and obese humans. New England Journal of Medicine 334 292-295.

Donahoo WT, Jensen DR, Yost TJ \& Eckel RH 1997 Isoproterenol and somatostatin decrease plasma leptin in humans: a novel mechanism regulating leptin secretion. Journal of Clinical Endocrinology and Metabolism 82 4139-4143.

Gambacciani M, Ciaponi M, Cappagli B, Piaggesi L, De Simone L, Orlandi R \& Genazzani AR 1997 Body weight, body fat distribution, and hormonal replacement therapy in early postmenopausal women. Journal of Clinical Endocrinology and Metabolism 82 414-417.

Gray JM \& Wade GN 1980 Cytoplasmic estrogen, but not progestin, binding sites in male rat adipose tissues. American Journal of Physiology 239 E237-E241

Haarbo J, Marslew U, Gotfredsen A \& Christiansen C 1991 Postmenopausal hormone replacement therapy prevents central distribution of body fat after menopause. Metabolism 40 1323-1326.

Haffner SM, Mykkanen L \& Stern MP 1997 Leptin concentrations in women in the San Antonio Heart Study: effect of menopausal status and postmenopausal hormone replacement therapy. American Journal of Epidemiology 146 581-585.

Haffner SM, Mykkanen LA, Gonzalez CC \& Stern MP 1998 Leptin concentrations do not predict weight gain: the Mexico City Diabetes Study. International Journal of Obesity 22 695-699.

Hardie L, Trayhurn P, Abramovich D \& Fowler P 1997 Circulating leptin in women: a longitudinal study in the menstrual cycle and during pregnancy. Clinical Endocrinology 47 101-106.

Hassager C \& Christiansen C 1989 Estrogen/gestagen therapy changes soft tissue body composition in postmenopausal women. Metabolism 38 662-665.

Havel PJ, Kasim-Karakas S, Dubuc GR, Mueller W \& Phinney SD 1996 Gender differences in plasma leptin concentrations. Nature Medicine 2 949-950.

Hube F, Lietz U, Igel M, Jensen PB, Tornqvist H, Joost HG \& Hauner H 1996. Difference in leptin mRNA levels between omental and subcutaneous abdominal adipose tissue from obese humans. Hormone and Metabolic Research 28 690-693.

Kolaczynski JW, Nyce MR, Considine RV, Boden G, Nolan JJ, Henry R, Mudaliar SR, Olefsky J \& Caro JF 1996 Acute and chronic effects of insulin on leptin production in humans: studies in vivo and in vitro. Diabetes 45 699-701.

Kristensen K, Pedersen SB, Fisker S, Norrelund H, Rosenfalck AM, Jorgensen JOL \& Richelsen B 1998 Serum leptin levels and leptin expression in growth hormone (GH)-deficient and healthy adults: influence of GH treatment, gender, and fasting. Metabolism 47 1514-1519.

Kritz-Silverstein D \& Barrett-Connor E 1996 Long-term postmenopausal hormone use, obesity, and fat distribution in older women. Journal of the American Medical Association 275 46-49.

Masuzaki H, Ogawa Y, Isse N, Satoh N, Okazaki T, Shigemoto M, Mori K, Tamura N, Hosoda K, Yoshimasa Y, Jingami H, Kawasa T \& Nakao K 1995 Human obese gene expression. Adipocytespecific expression and regional differences in the adipose tissue. Diabetes 44 855-858.

Masuzaki H, Ogawa Y, Hosoda K, Miyawaki T, Hanaoka I, Hiraoka J, Yasuno A, Nishimura H, Yoshimasa Y, Nishi S \& Nakao K 1997 Glucocorticoid regulation of leptin synthesis and secretion in humans: elevated plasma leptin levels in Cushing's syndrome. Journal of Clinical Endocrinology and Metabolism 82 2542-2547.

McElroy JF \& Wade GN 1987 Short- and long-term effects of ovariectomy on food intake, body weight, carcass composition, and brown adipose tissue in rats. Physiology and Behavior 39 361-365.

Minami T, Oomura Y, Nabekura J \& Fukuda A 199017 betaestradiol depolarization of hypothalamic neurons is mediated by cyclic AMP. Brain Research 519 301-307.

Moller N, Obrien P \& Nair KS 1998 Disruption of the relationship between fat content and leptin levels with aging in humans. Journal of Clinical Endocrinology and Metabolism 83 931-934.

Montague CT, Prins JB, Sanders L, Digby JE \& O’Rahilly S 1997 Depot- and sex-specific differences in human leptin mRNA expression: implications for the control of regional fat distribution. Diabetes 46 342-347.

Nachtigall LE, Nachtigall RH, Nachtigall RD \& Beckman EM 1979 Estrogen replacement therapy II: a prospective study in the relationship to carcinoma and cardiovascular and metabolic problems. Obstetrics and Gynecology 54 74-79.

Nagy TR, Davies SL, Hunter GR, Darnell B \& Weinsier RL 1998 Serum leptin concentrations and weight gain in postobese, postmenopausal women. Obesity Research 6 257-261.

Notelovitz M, Ware MD \& Dougherty MC 1982 Blood pressure and body weight of postmenopausal women after one year of estrogenprogestin therapy. Current Therapy Research 31 746-751.

Ostlund RE Jr, Yang JW, Klein S \& Gingerich R 1996 Relation between plasma leptin concentration and body fat, gender, diet, age, and metabolic covariates. Journal of Clinical Endocrinology and Metabolism 81 3909-3913.

Pasquali R, Casimirri F, Labate AM, Tortelli O, Pascal G, Anconetani B, Gatto MR, Flamia R, Capelli M \& Barbara L 1994 Body weight, fat distribution and the menopausal status in women. The VMH Collaborative Group. International Journal of Obesity and Related Metabolic Disorders 18 614-621.

Pedersen SB, Børglum J, Eriksen EF \& Richelsen B 1991 Nuclear estadiol binding in rat adipocytes. Regional variations and regulatory influences of hormones. Biochimica et Biophysica Acta 1093 80-86.

Pedersen SB, Fuglsig S, Sjogren P \& Richelsen B 1996a Identification of steroid receptors in human adipose tissue. European Journal of Clinical Investigation 26 1051-1056.

Pedersen SB, Hansen PS, Lund S, Andersen PH, Odgaard A \& Richelsen B $1996 b$ Identification of oestrogen receptors and oestrogen receptor mRNA in human adipose tissue. European Journal of Clinical Investigation 26 262-269.

Price TM, O'Brien SN, Welter BH, George R, Anandjiwala J \& Kilgore M 1998 Estrogen regulation of adipose tissue lipoprotein lipase - possible mechanism of body fat distribution. American Journal of Obstetrics and Gynecology 178 101-107.

Ravussin E, Pratley RE, Maffei M, Wang H, Friedman JM, Bennett PH \& Bogardus C 1997 Relatively low plasma leptin concentrations precede weight gain in Pima Indians. Nature Medicine 3 $238-240$ 
Rosenbaum M, Nicolson M, Hirsch J, Heymsfield SB, Gallagher D, Chu F \& Leibel RL 1996 Effects of gender, body composition, and menopause on plasma concentrations of leptin. Journal of Clinical Endocrinology and Metabolism 81 3424-3427.

Roubenoff R, Dallal GE \& Wilson PW 1995 Predicting body fatness: the body mass index vs estimation by bioelectrical impedance. American Journal of Public Health 85 726-728.

Shimizu H \& Bray GA 1993 Effects of castration, estrogen replacement and estrus cycle on monoamine metabolism in the nucleus accumbens, measured by microdialysis. Brain Research $\mathbf{6 2 1}$ 200-206.

Shimizu H, Ohtani K, Kato Y, Tanaka Y \& Mori M 1996 Withdrawal of [corrected] estrogen increases hypothalamic neuropeptide Y (NPY) mRNA expression in ovariectomized obese rats. Neuroscience Letters 204 81-84.

Shimizu H, Shimomura Y, Nakanishi Y, Futawatari T, Ohtani K, Sato N \& Mori M 1997 Estrogen increases in vivo leptin production in rats and human subjects. Journal of Endocrinology 154 285-292.

Svendsen OL, Hassager C \& Christiansen C 1995 Age- and menopause-associated variations in body composition and fat distribution in healthy women as measured by dual-energy X-ray absorptiometry. Metabolism 44 369-373.
Szymczak J, Milewicz A, Thijssen JH, Blankenstein MA \& Daroszewski J 1998 Concentration of sex steroids in adipose tissue after menopause. Steroids 63 319-321.

Vallette G, Christeff N, Bogard C, Benassayag C \& Nunez E 1988 Dynamic pattern of estradiol binding to uterine receptors of the rat. Inhibition and stimulation by unsaturated fatty acids. Journal of Biology and Chemistry 263 3639-3645.

Wabitsch M, Jensen PB, Blum WF, Christoffersen CT, Englaro P, Heinze E, Rascher W, Teller W, Tornqvist H \& Hauner H 1996 Insulin and cortisol promote leptin production in cultured human fat cells. Diabetes 45 1435-1438.

World Health Organization 1997 Obesity. Preventing and Managing the Global Epidemic. Geneva: WHO.

Zimmet P, Hodge A, Nicolson M, Staten M, de Courten M, Moore J, Morawiecki A, Lubina J, Collier G, Alberti G \& Dowse G 1996 Serum leptin concentration, obesity, and insulin resistance in Western Samoans: cross sectional study. British Medical Journal 313 965-969.

Received 11 December 1998

Revised manuscript received 5 May 1999

Accepted 12 May 1999 